\title{
Antioxidant, Anti-Inflammatory Efficacy and HPLC Analysis of Annona muricata Leaves Extracts from Republic of Benin
}

\author{
Kohonou Arnaud1', Chabi Nicodème ${ }^{1}$, Dah-Nouvlessounon Durand ${ }^{2}$, Nounagnon Martial2, \\ Sognigbe Basile1, Sina Haziz², N'Tcha Christine' ${ }^{2}$, Kohonou A. Christian', Lehmane Halfane', \\ Dougnon Victorien ${ }^{3}$, Pacôme Noumavo², Baba-Moussa Lamine ${ }^{2}$
}

${ }^{1}$ Laboratory of Research in Applied Biology, Polytechnic School of Abomey-Calavi, University of Abomey-Calavi, Cotonou, Benin ${ }^{2}$ Laboratory of Biology and Molecular Typing in Microbiology, Department of Biochemistry and Cell Biology, Faculty of Science and Technology, University of Abomey-Calavi, Cotonou, Bénin ${ }^{3}$ Research Unit in Applied Microbiology and Pharmacology of Natural Substances, Laboratory of Research in Applied Biology, Polytechnic School of Abomey-Calavi, University of Abomey-Calavi, Cotonou, Benin

Email: *nicodeme.chabi@gmail.com

How to cite this paper: Arnaud, K., Nicodème, C., Durand, D.-N., Martial, N., Basile, S., Haziz, S., Christine, N., Christian, K.A., Halfane, L., Victorien, D., Noumavo, P. and Lamine, B.-M. (2020) Antioxidant, Anti-Inflammatory Efficacy and HPLC Analysis of Annona muricata Leaves Extracts from Republic of Benin. American Journal of Plant Sciences, 11, 803-818.

https://doi.org/10.4236/ajps.2020.116057

Received: April 24, 2019

Accepted: June 21, 2020

Published: June 24, 2020

Copyright $\odot 2020$ by author(s) and Scientific Research Publishing Inc. This work is licensed under the Creative Commons Attribution International License (CC BY 4.0).

http://creativecommons.org/licenses/by/4.0/ (c) (i) Open Access

\begin{abstract}
Annona muricata L. (Soursop or Graviola) is a naturally occurring plant seen in Southern part of Africa, traditionally used in Benin to treat various diseases. The present study aimed to investigate phytochemical composition and antioxidant, anti-inflammatory activities of $A$. muricata leaves extracts. The secondary metabolites of ethanolic and hemi-ethanolic extracts were analysed by HPLC method. The DPPH and FRAP methods were used to evaluate the antioxidant activity. Inhibition of albumin denaturation method was used to evaluate anti-inflammatory activity of the tested extracts of which larval cytotoxicity was studied. The major identified compounds were gallic acid, chlorogenic acid, cafeic acid, tannic acid, ferrulic acid, Rutin. Ascorbic acid exhibited the highest inhibition percentage $(83.33 \% \pm 0.50 \%)$ of DPPH radical with the lowest $\mathrm{IC}_{50}(45.1 \pm 0.28 \mu \mathrm{g} / \mathrm{ml})$. The inhibition of the ferric ion $\mathrm{Fe}^{3+}$ varied $(p=0.0013)$ according to the extracts type. $\mathrm{IC}_{50}$ values of ferric ion inhibition range from $119.5 \pm 3.10$ to $250.8 \pm 2.13 \mu \mathrm{g} / \mathrm{ml}$ respectively for A. muricata leaves ethanol and hemi-ethanolic extracts. The hemi-ethanolic extract exhibited the highest anti-inflammatory activity $(96.66 \% \pm 1.17 \%)$. The presence of phenolic compound confers to A. muricata leaves, through the ethanolic and the hemi-ethanolic extracts, the antioxidant and anti-inflammatory activities.
\end{abstract}

\section{Keywords}

A. muricata, Secondary Metabolites Extracts, Screening, Biological Activities, 
Benin

\section{Introduction}

Plants are known to be rich sources of bioactive compound [1]. Generally, plant bioactive compounds differ greatly in terms of their quality and quantity, depending on the plant or on the various constituent parts of the plant [2] and they have been widely assessed for their biological properties [3]. In Africa, the population used various plants to treat all kinds of chronic diseases among which due to oxidative stress and that linked to metabolism [4]. Oxidative stress has been implicated in the pathology of numerous conditions, including aging, inflammatory disorders, diabetes, cancer, muscle wasting and muscular dystrophies [5]. Reactive oxygen species (ROS) cause cellular damage by directly and irreversibly altering macromolecules such as proteins, membrane lipids and DNA [6], but another (less studied) major cellular consequence of ROS exposure is the reversible modification of protein thiol side chains that may affect many aspects of molecular function [5]. However, medicinal plants contained the secondary metabolites that scientific research has proved their therapeutic effects over time [7]. Recent research supports the role of these types of secondary metabolites in the prevention of degenerative diseases, especially cancer, cardiovascular diseases, and neurodegenerative diseases [8]. Polyphenols and flavonoids are strong antioxidants that complete and add to the functionalities of vitamins and antioxidant enzymes with the purpose of defense against oxidative stress caused by the excessive presence of reactive oxygen species (ROS) [9]. Reactive oxygen species (ROS) are key signaling molecules that play an important role in the progression of inflammatory disorders [10].

The free radicals especially, the reactive oxygen species (ROS) create oxidative stress in the cells leading to inflammatory and infectious condition. Phagocytic cells including polymorphonuclear leukocytes (neutrophils, eosinophils) and mononuclear cells (macrophages and lymphocytes) produce excessive amount of ROS which play an important role in the host defense mechanism. Besides their defensive effects these excessively produced ROS which deregulate the cellular functions causing cellular and tissue damage, which in turn increases the state of inflammation [11]. Non-steroidal anti-inflammatory drugs (NSAIDs) represent one of the most common classes of medications used worldwide for inflammation and related disorders [12]. Unfortunately, besides the excellent anti-inflammatory potential of the NSAIDs, the severe side effects such as gastrointestinal (GI) ulceration, perforation, obstruction, and bleeding have limited the therapeutic usage of NSAID [13].

Natural antioxidants from plants play an important role in maintaining general health [14]. Several studies report that medicinal plants are used as solution to many diseases and are the source of news compounds. Furthermore, novel antioxidant, anti-inflammatory drugs or adjuvant that lower the quantities of 
synthetics drugs to achieve eradication of diseases linked to the ROS with lower toxicity are urgently required [15]. Since traditional medicine involves the use of plant extracts which contains an extensive diversity of compounds, often with indefinite biological effects there is need to determine the toxicity of medicinal plants. The one approach to evaluate cytotoxicity is the study using Brine-Shrimp lethality assay [16]. The brine shrimp lethality test is used to predict compounds or extracts with toxicity or that may have anticancer activity [17].

Annona muricata L. (AML), family Annonaceae has been used as a natural solution for the treatment of many diseases in Benin. Previous reports over the years have demonstrated that roots, stem, bark, leaf, fruit and seed extracts of $A$. muricata are anti-bacterial [18]. Its leaf extract was also found to possess antioxidant [18] and molluscicidal properties [19]. Recently, it has also been reported to exhibit anti-inflammatory and analgesic effects [20]. Among the chemical constituents found in the leaf of $A$. muricata are alkaloids [21], essential oils [22] and acetogenins [23].

The aim of this study is to evaluate biological activities (anti-oxidant, anti-inflammatory and cytotoxicity) of phytochemical compounds contained in $A$. muricata leaves extracts.

\section{Material and Methods}

\subsection{Plant Material and Extracts Preparation}

A. muricata leaves were collected in Tchaada village (Southern Benin) and air dried at $25^{\circ} \mathrm{C}-30^{\circ} \mathrm{C}$ (laboratory conditions) for two weeks, grinded and sieved into a bark powder. The extracts were obtained according to the method describe by Dah-Nouvlessounon et al. [24]. Briefly, the powder $(50 \mathrm{~g})$ of leaf powder was macerated into $500 \mathrm{ml}$ of each solvent: Ethanol and the mixture water/ethanol $(30 / 70 \mathrm{v} / \mathrm{v})$, under agitator for $72 \mathrm{~h}$ at room temperature. Each homogenate was then filtered two times on absorbent cotton and once on Whatman $\mathrm{N}^{\circ} 1$ paper $(125 \mathrm{~mm} ø$, Cat No 1001 125). The filtrate was concentrated in vacuum using a Rotary evaporator (Heidolph Instruments $\mathrm{GmbH} \&$ Co. KG No: 591-28000-00-1). The concentrated was dried in the oven at $40^{\circ} \mathrm{C}$; the obtained powder is considered as the total extract ready to use for the biological activities. All extracts were stored in labeled sterile bottles and kept at $-20^{\circ} \mathrm{C}$ until further use.

\subsection{Preliminary Phytochemical Screening}

The leaves powder was subjected to the qualitative phytochemical investigation to identify the major components (nitrogenous, polyphenolic and terpenic compounds, and glycosides) who was done according to previous report [25].

\subsection{HPLC Analysis}

Phenolic compounds were identified using standard molecules and a High Per- 
formance Liquid Chromatography analytical system (U-HPLC-DAD) equiped with a degasser, a binary gradient pump, a UV detector at multiple wavelengths (DAD-3000 RS and MWD-3000 RS) and a reverse phase column (C18; $150 \times 4.6$ $\mathrm{mm}, 5 \mu \mathrm{m}$; Hypersil BDS). The samples were prepared at $1 \mathrm{mg} / \mathrm{ml}$. The mobile phases consisted of acidified distilled water 1 ) with $0.1 \%$ formic acid and acidified acetonitrile 2) with $0.1 \%$ formic acid. The elution gradient is as follow: 0 - 20 $\min , 20 \%-50 \%$ B; 20 - 25 min. 50\% - 70\% B; 25 - 30 min, 70\% - 80\% B; $30-35$ $\mathrm{min}, 80 \%-20 \% \mathrm{~B}, 35-40 \mathrm{~min}, 20 \% \mathrm{~B}$, with a flow rate of $1 \mathrm{ml} / \mathrm{min}$ and an injection volume of $20 \mu \mathrm{l}$. Data analysis was performed using Chromleon v.6.80 software (Dionex, Thermo Fisher Scientific).

\subsection{1,1-Diphenyl-2-Picrylhydrazyl (DPPH) Radical Scavenging Activity}

The DPPH method was conducted by adaptation as described by Scherer and Godoy [26]. Equal volumes $(1000 \mu \mathrm{l})$ of DPPH $(50 \mu \mathrm{M})$ and plant extracts (2000 $\mu \mathrm{g} / \mathrm{ml}$ ) were mixed and allowed to stand in darkness for $20-30 \mathrm{~min}$ at room temperature. Then, the absorbance was read at $517 \mathrm{~nm}$ and the blank was a mixture of methanol and DPPH (v:v). The inhibitory percentage of DPPH radical indicating the antioxidant activity of extracts and BHA, ascorbic acid was obtain using the formula establish by Schmeda-Hirschmann et al. [27].

The Concentration providing 50\% inhibition $\left(\mathrm{IC}_{50}\right)$ was determined graphically using a calibration curve in the linear range by plotting the extract concentration and the corresponding scavenging effect.

\subsection{Ferric Reducing/Antioxidant Power (FRAP) Assay}

The ferric reducing power of $A$. muricata extracts was determined according to the method described in literature [28]. Thus, $0.4 \mathrm{ml}$ of sample at different concentrations was mixed with $1 \mathrm{ml}$ of phosphate buffer $(0.2 \mathrm{M}, \mathrm{pH}=6.6)$ and $1 \mathrm{ml}$ of $1 \%$ potassium hexacyanoferrate $[\mathrm{K} 3 \mathrm{Fe}(\mathrm{CN}) 6]$. After incubating at $50^{\circ} \mathrm{C}$ for 30 minutes, $1 \mathrm{ml}$ of $10 \%$ trichloroacetic acid was added, tubes were centrifuged at $3000 \mathrm{rpm}$ for 10 minutes. Then $1 \mathrm{ml}$ of supernatant was mixed with $0.2 \mathrm{ml}$ of $0.1 \% \mathrm{FeCl} 3$ solution and suspended in the dark for 30 minutes before measuring the absorbances at $700 \mathrm{~nm}$.

\subsection{Anti-Inflammatory Activity Essay}

In vitro anti-inflammatory activity of $A$. muricata leaves extracts was evaluated with inhibition of albumin denaturation method [29]. Briefly, the $5 \mathrm{ml}$ of reaction mixture was comprised of $0.2 \mathrm{ml}$ of eggs albumin, $2.8 \mathrm{ml}$ of phosphate buffered saline (PBS, pH 6.4) and $2 \mathrm{ml}$ of varying concentration of extracts $(1000 ; 500 ; 250 ; 125 ; 62.5 ; 31.5 \mu \mathrm{g} / \mathrm{ml})$. Similar volume of double distilled water served a control. Then the mixture was incubated at $37^{\circ} \mathrm{C}$ in incubator for about 15 mins and then heated at $70^{\circ} \mathrm{C}$ for 5 mins. After cooling, their absorbance was measured at $660 \mathrm{~nm}$ by using pure blank. Diclofenac sodium inj. 
$\mathrm{Pb}$./Drugs/1804-BManufactured for Pharma plus (standard drug) at the concentration range from 6.25 to $25 \mathrm{mg} / \mathrm{ml}$ was used as reference drug and treated as such for determination of absorbance. The percentage inhibition of protein denaturation was calculated by the formula mentioned below.

$$
\% \text { inhibition }=\frac{\text { Abs Control }- \text { Abs sample }}{\text { Abs Control }}
$$

\subsection{Cytotoxicity Essay}

The cytotoxic effect of the extracts was evaluated according to an adaptation of the method described by Kawsar et al. [30]. The tests are carried out twice on 72 h larvae of Artemia salina. Briefly, a test was constituted of $16 \mathrm{~A}$. salina larvae in a $2 \mathrm{ml}$ solution containing $1 \mathrm{ml}$ of the extract tested concentration and $1 \mathrm{ml}$ of sea. The number of surviving larvae is counted after incubation $(24 \mathrm{~h})$ and the $\mathrm{DL}_{50}$ was calculated using the regression line obtained from the surviving larvae in function of the extracts concentration representation.

\subsection{Statistical Analysis}

Biological activities experimentation was done in triplicate and data thus obtained reported as a mean \pm standard deviation (SD). The data were analyzed using Graph Pad Prism 7 software. Differences of $p<0.05$ were considered significant.

\section{Results}

\subsection{Preliminary Phytochemical Screening}

The secondary metabolites detected in A. muricata leaves extracts are summarized in Table 1. It was noted an uneven distribution of these metabolites from one extract to another. Indeed, $64.70 \%$ of the studied secondary metabolites were present in the hemi-ethanolic extract against $29.41 \%$ in the ethanolic extract.

\subsection{HPLC Analysis}

The HPLC analysis of ethanolic and hemi-ethanolic extracts of $A$. muricata leaves extracts has shown the presence of various (60) polyphenolic compounds. The major identified compounds were gallic acid, chlorogenic acid, cafeic acid, tanic acid, ferrulic acid, Rutin, Ellargic acid (Table 2). Quantitatively, tannic acid was the major identified components $(4.534 \mu \mathrm{g} / \mathrm{ml}$ with ethanolic extract and $3.586 \mu \mathrm{g} / \mathrm{ml}$ with hemi-ethanolic extract). Beside, for ethanolic extract, ferrulic acid recorded the lowest amount $(0.001 \mu \mathrm{g} / \mathrm{ml})$ while gallic acid has the lowest compound $(0.005 \mu \mathrm{g} / \mathrm{ml})$ in hemi-ethanolic extract.

\subsection{DPPH Radical Scavenging Activity}

The DPPH radical scavenging activity of the extracts and reference molecules are 
presented in Figure 1(a) and Figure 1(b) respectively. The data showed, a dose response activity according to the extracts and reference molecules. Indeed, the percentages of free radical inhibition increased as concentration increased in the both products (extracts and reference molecules). Considering the extracts, the highest inhibition percentage $(80.59 \% \pm 0.58 \%)$ was obtained with the hemi-ethanolic extracts at $1000 \mu \mathrm{g} / \mathrm{ml}$. However, with the reference molecules, ascorbic acid exhibited the highest inhibition percentage $(83.33 \% \pm 0.50 \%)$ at 1000 $\mu \mathrm{g} / \mathrm{ml}$. Besides, the lowest $\mathrm{IC}_{50}(45.1 \pm 0.28 \mu \mathrm{g} / \mathrm{ml})$ was obtained with ascorbic acid followed by the ethanolic extract $\left(\mathrm{IC}_{50}=50.01 \pm 0.16 \mu \mathrm{g} / \mathrm{ml}\right.$ ), followed by the hemi-ethanolic extract $\left(\mathrm{IC}_{50}=80.50 \pm 0.48 \mu \mathrm{g} / \mathrm{ml}\right)$ and at the end of the BHA $\left(\mathrm{IC}_{50}=104.01 \pm 0.13 \mu \mathrm{g} / \mathrm{ml}\right)$.

The multivariate analysis of variance (Table 3 ) shows that the inhibition percentage the free radical DPPH vary on the one hand according to the extracts ( $p$ $<0.0001)$ and their concentrations $(p<0.0001)$ and on the other hand according to the reference molecules $(p<0.0001)$.

Table 1. Phytochemical constituents of $A$. muricata extracts.

\begin{tabular}{|c|c|c|c|}
\hline \multirow{2}{*}{ Group of compounds } & \multirow{2}{*}{ Class } & \multicolumn{2}{|c|}{ A. muricata extracts } \\
\hline & & EtOH & $\mathrm{EtOH} / \mathrm{H}_{2} \mathrm{O}$ \\
\hline \multirow[t]{5}{*}{ Nitrogenous compounds } & Alkaloids & + & + \\
\hline & Tannins & - & + \\
\hline & Catechic tanins & - & + \\
\hline & Gallic tanins & - & + \\
\hline & Flavonoids & + & + \\
\hline \multicolumn{4}{|l|}{ Poly-phenolic compounds } \\
\hline & Anthocyans & + & + \\
\hline & Leuco-anthocyanes & + & + \\
\hline & Coumarin & - & - \\
\hline & Quinonics derivate & - & + \\
\hline & Triterpenoids & - & - \\
\hline \multicolumn{4}{|l|}{ Terpenic compounds } \\
\hline & Steroids & - & - \\
\hline & Reducing compounds & + & + \\
\hline & Free anthracenics & - & - \\
\hline & O-heterosides & - & + \\
\hline \multicolumn{4}{|l|}{ Heterosides } \\
\hline & O-heterosides at GR & - & - \\
\hline & C-heterosides & - & - \\
\hline & Mucilags & - & + \\
\hline
\end{tabular}

(+): Presence of secondary metabolite. (-): Absence of secondary metabolite. 
Table 2. Major phenolic compounds identified in ethanolic and hemi-ethanolic extracts of $A$. muricata by HPLC.

\begin{tabular}{ccccccc}
\hline \multirow{2}{*}{ No } & \multirow{2}{*}{ Compounds } & $\mathrm{T}_{\mathrm{R}}$ min & \multicolumn{2}{c}{ Rel. Area (\%) } & \multicolumn{2}{c}{ Amount $\mu \mathrm{gg} / \mathrm{ml}$} \\
\cline { 5 - 7 } & & EtOH & EtOH/ $\mathrm{H}_{2} \mathrm{O}$ & EtOH & EtOH/ $\mathrm{H}_{2} \mathrm{O}$ \\
\hline 1 & Gallic acid & 3.30 & 0.75 & 0.12 & 0.013 & 0.005 \\
2 & Chlorogenic acid & 6.92 & 2.59 & 2.97 & 0.130 & 0.358 \\
3 & Cafeic acid & 8.32 & 0.12 & 0.42 & 0.002 & 0.021 \\
4 & Tannic acid & 10.71 & 0.55 & 0.29 & 3.586 & 4.534 \\
5 & Ferrulic acid & 11.95 & 0.02 & 0.10 & 0.001 & 0.010 \\
6 & Rutin & 17.61 & 4.76 & 2.42 & 0.086 & 0.106 \\
7 & Ellagic acid & 18.18 & 7.27 & 5.77 & 0.085 & 0.163 \\
\hline
\end{tabular}

EtOH: ethanolic extract; EtOH/ $\mathrm{H}_{2} \mathrm{O}$ : hemi-ethanolic extract.

Table 3. Summary of ANOVA Multivariate analysis of DPPH radical scavenging activity.

\begin{tabular}{|c|c|c|c|c|c|c|}
\hline \multirow{2}{*}{ Variables } & \multicolumn{6}{|c|}{ Summary ( $p$-value) } \\
\hline & $1000 \mu \mathrm{g} / \mathrm{ml}$ & $500 \mu \mathrm{g} / \mathrm{ml}$ & $250 \mu \mathrm{g} / \mathrm{ml}$ & $125 \mu \mathrm{g} / \mathrm{ml}$ & $62.5 \mu \mathrm{g} / \mathrm{ml}$ & $31.25 \mu \mathrm{g} / \mathrm{ml}$ \\
\hline $\mathrm{EtOH} / \mathrm{H}_{2} \mathrm{O} \boldsymbol{v} \boldsymbol{s} . \mathrm{EtOH}$ & $<0.0001$ & ns & $<0.0001$ & $<0.0001$ & $<0.0001$ & $<0.0001$ \\
\hline $\mathrm{EtOH} / \mathrm{H}_{2} \mathrm{O} v \boldsymbol{s} . \mathrm{BHA}$ & 0.0219 & ns & $<0.0001$ & $<0.0001$ & ns & $<0.0001$ \\
\hline $\mathrm{EtOH} / \mathrm{H}_{2} \mathrm{O}$ vs. Asc.ac & 0.0065 & 0.0011 & ns & $<0.0001$ & $<0.0001$ & $<0.0001$ \\
\hline EtOH vs. BHA & 0.0087 & 0.0403 & $<0.0001$ & $<0.0001$ & $<0.0001$ & ns \\
\hline EtOH vs. Asc. ac & $<0.0001$ & $<0.0001$ & $<0.0001$ & $<0.0001$ & $<0.0001$ & $<0.0001$ \\
\hline BHA vs. Asc. ac & $<0.0001$ & 0.0061 & $<0.0001$ & $<0.0001$ & $<0.0001$ & $<0.0001$ \\
\hline
\end{tabular}

Asc. ac: Ascorbic acid; ns: not significant ( $p>0.05)$; EtOH: ethanolic extract; $\mathrm{EtOH} / \mathrm{H}_{2} \mathrm{O}$ : hemi-ethanolic extract; BHA: Buthylhydroxyanisol.

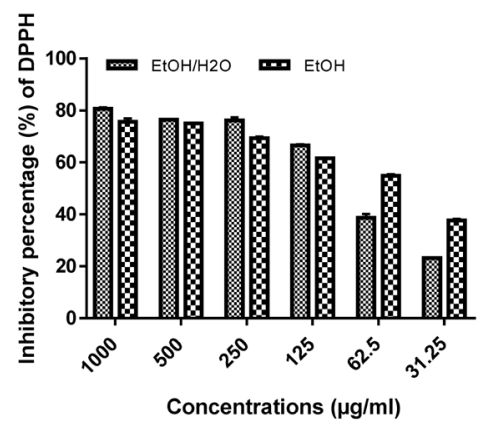

(a) extracts

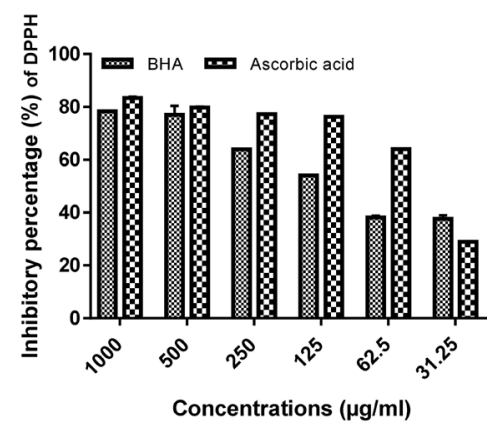

(b) Reference molecules

Figure 1. DPPH inhibition percentage of $A$. muricata leaves extracts (a) and reference molecules (b). Values are expressed in mean \pm S.E.M. of triplicate measurement $(n=3)$.

The antioxidant activity index (AAI), expressing the anti-free radical power of the extracts and reference molecules was presented in Figure 2. It appears through this figure that ascorbic acid has the strongest antioxidant power (AAI $=1.10 \pm 0.007)$ while BHA had the lowest antioxidant power $(\mathrm{AAI}=0.48 \pm$ 0.001). Furthermore, the results show that the two extracts of $A$. muricata have antioxidant powers superior to those of reference molecule (BHA). However, $A$. 
muricata leaves ethanolic extract has a higher antioxidant power than that of the leaves hemi-ethanol extract. As summarized, assay shows that, in this system, the radical-scavenging activities of differents products (extracts and reference molecules) are in the order: ascobic acid $>$ Ethnol extract $>$ water-ethanol extract $>$ BHA.

\subsection{Ferric Ion Reducing Power}

Ferric Reducing/antioxydant Power by $A$. muricata extracts is presented in Figure 3. A dose-dependent activity was observed between the $A$. muricata leaves ethanolic and hemi-ethanolic extracts. The highest percentages were obtained at $1000 \mu \mathrm{g} / \mathrm{ml}$. In addition, the inhibition percentages of the ferric ion $\mathrm{Fe}^{3+}$ vary from $55.03 \% \pm 0.04 \%$ (ethanolic extract) to $11.94 \% \pm 0.12 \%$ obtained with the hemi-ethanolic extract at $31.25 \mu \mathrm{g} / \mathrm{ml}$. However, the inhibition gradient of extracts concentrations made it possible to determine the $\mathrm{IC}_{50}$ 's which are $250.8 \pm$ $2.13 \mu \mathrm{g} / \mathrm{ml}$ and $119.5 \pm 3.10 \mu \mathrm{g} / \mathrm{ml}$ respectively for A. muricata leaves ethanolic and hemi-ethanolic extracts. The analysis of variance shows that the interaction between the inhibiting power of the extracts (ethanolic and hemi-ethanolic) varies according to their concentrations. Indeed, the inhibition percentage of ethanolic and hemi-ethanolic extracts varied significantly $(p=0.0013)$ at 1000 $\mu \mathrm{g} / \mathrm{ml}$. This variation is highly significant $(p=0.0005)$ at $250 \mu \mathrm{g} / \mathrm{ml}$ and very highly significant $(p<0.0001)$ at the concentrations of 62.5 and $31.25 \mu \mathrm{g} / \mathrm{ml}$. Furthermore, no variation $(p>0.05)$ was observed for 500 and $125 \mu \mathrm{g} / \mathrm{ml}$.

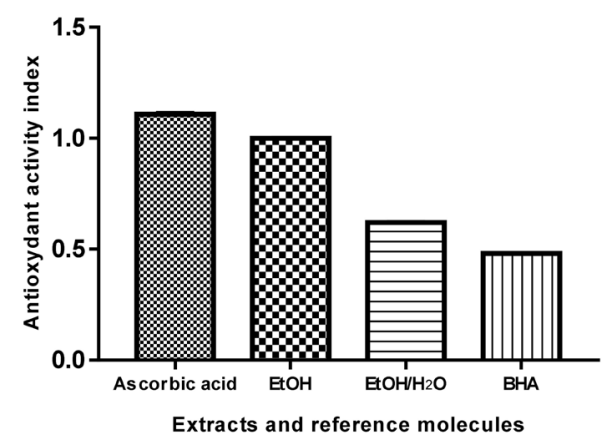

Figure 2. Antioxydant activity index (AAI) of $A$. muricata extracts and reference molecules.

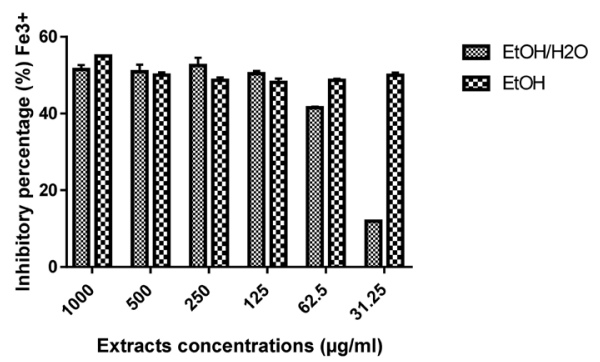

Figure 3. Ferric ion reducing power of $A$. muricata ethanolic and hemi-ethanolic extracts. Values are expressed in mean \pm S.E.M. of triplicate measurement $(n=3)$. 


\subsection{Anti-Inflammatory Activity}

In vitro anti-inflammatory effect of $A$. muricata extracts are summarized in the Table 4. The results showed that the extracts exhibited a concentration dependent inhibition of protein (egg albumin) denaturation throughout the concentration range from 31.25 to $1000 \mu \mathrm{g} / \mathrm{ml}$. Indeed, the higher inhibition percentage obtained with hemi-ethanolic extract was $96.66 \% \pm 1.17 \%$, while the highest recorded with ethanolic extract was $87.12 \% \pm 0.53 \%$. Then, variance analysis showed the difference $(p<0.0001)$ between inhibition percentage of protein (egg albumin) denaturation considering the concentration range from 62.5 to 1000 $\mu \mathrm{g} / \mathrm{ml}$ while there is no difference $(p>0.05)$ between the inhibition percentage at $31.25 \mu \mathrm{g} / \mathrm{ml}$. However, the hemi-ethanolic extract was more active than those of ethanolic extract. This was further confirmed by comparing their $\mathrm{IC}_{50}$ values. Indeed, A. muricata hemi-ethanolic extracts display the high inhibition of protein (egg albumin) denaturation with the lowest concentration $\left(\mathrm{IC}_{50}=44.3 \pm\right.$ $0.28 \mu \mathrm{g} / \mathrm{ml}$ ) compared to those obtained with ethanolic extract $\left(\mathrm{IC}_{50}=187.95 \pm\right.$ $87.75 \mu \mathrm{g} / \mathrm{ml}$ ). Diclofenac sodium inj. (at the concentration range from 6.25 to 25 $\mathrm{mg} / \mathrm{ml}$ ) was used as reference drug which also exhibited concentration dependent inhibition of protein denaturation. The results showed that the high activity $(94.55 \% \pm 0.12 \%)$ of diclofenac was found at $25 \mathrm{mg} / \mathrm{ml}$ (Table 4). These results showed that $A$. muricata extracts have the good inhibition of protein denaturation comparing to reference drug (diclofenac sodium).

\subsection{Cytotoxicity Activity}

The bioassay to determine the lethality effect of $A$. muricata leaves extracts with Artemia salina model was presented in Figure 4. Indeed, the results showed the concentrations response activity. The larval mortality gradient was lowest with A. muricata ethanolic extract comparing to hemi-ethanolic extract. However, there is no difference $(p>0.05)$ between the $\mathrm{LD}_{50}$ values range from $5.21 \mathrm{mg} / \mathrm{ml}$; $\mathrm{r}^{2}=0.643$ (hemi-ethanolic extract) to $9.98 \mathrm{mg} / \mathrm{ml} ; \mathrm{r}^{2}=0.690$ (Ethanolic extract).

Table 4. In vitro anti-inflammatory activity of $A$. muricata leaves extracts.

\begin{tabular}{cccccc}
\hline \multicolumn{2}{c}{ Concentrations $(\mu \mathrm{g} / \mathrm{ml})$} & \multicolumn{5}{c}{ Inhibition percentage (\%) } \\
\hline Extracts & Diclofenac & EtOH & EtOH/H ${ }_{2} \mathrm{O}$ & Diclofenac & t-value \\
\hline 1000 & 25000 & $87.12 \pm 0.53$ & $96.66 \pm 1.17$ & $94.55 \pm 0.12$ & $9.23^{* * * *}$ \\
500 & 12500 & $82.12 \pm 0.53$ & $95.00 \pm 0.00$ & $89.10 \pm 0.25$ & $12.47^{* * *}$ \\
250 & 6250 & $50.00 \pm 0.00$ & $92.5 \pm 0.00$ & $87.23 \pm 0.37$ & $41.15^{* * *}$ \\
125 & - & $48.75 \pm 1.76$ & $87.5 \pm 0.00$ & - & $37.52^{* * * *}$ \\
62.5 & - & $16.25 \pm 1.76$ & $83.54 \pm 0.29$ & - & $65.15^{* * * *}$ \\
31.25 & - & $11.25 \pm 1.76$ & $10.83 \pm 1.17$ & - & $0.40^{\text {ns }}$ \\
$I_{50}(\mu \mathrm{g} / \mathrm{ml})$ & $187.95 \pm 87.75$ & $44.3 \pm 0.28$ & - & \\
\hline
\end{tabular}

Values are expressed in mean \pm S.E.M. of triplicate measurement $(n=3)$. 


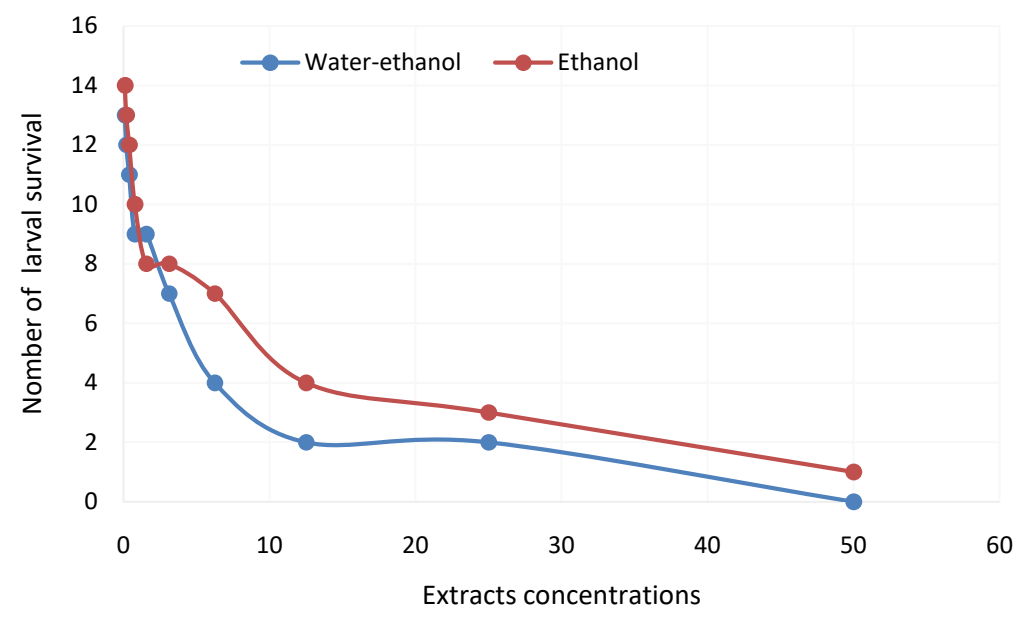

Figure 4. Variation of Artemia salina larval mortality according to A. muricata leaves extracts.

\section{Discussion}

The qualitative screening of $A$. muricata leaves extracts revealed the presence of various phytochemical components. Phytochemicals, such as phenolic compounds, are considered beneficial for human health, decreasing the risk of degenerative diseases by reduction of oxidative stress and inhibition of macro-molecular oxidation [31]. These compounds have been reported to be well correlated with antioxidant potential [32]. The presence of alkaloids and flavonoids (anthocyans and leuco-anthocyans) in the both extracts (ethanolic and hemi-ethanolic) indicate their potentiality to reduce in vitro cholesterol agents and to induce an many biological activity [33] because flavoinoids has an group of phenolics compounds involved in many biological effects [33] such as anti-inflammatory activity [34], antioxidant, hepatoprotective activities [35].

The study of the antioxidant activity in natural products has received increasing attention in recent years. Several in vitro methods have been used to assess the antioxidant activity in naturals products, including, 1,1-diphenyl-2-picrylhydrazyl (DPPH) radical [36], FRAP ferric reducing/ antioxidant power assay [32]. To evaluate antioxidant activity of $A$. muricata leaves extracts in this study, these two methods was used. The both extracts revealed significant scavenging of DPPH free radicals in dose-dependend manner and this may be attributed to their electron donating ability. The $\mathrm{IC}_{50}$ values show that $A$. muricata leaves extracts display anti-free radical activity greater than those of BHA which is a reference molecule. Baskar et al. [37] and George et al. [38] show that A. muricata leave extracts (methanolic and aqueous) from India have DPPH radical scavenging activity. Then these observations show that $A$. muricata extracts might prevent reactive radical species from damaging biomolecules in susceptible biological and food systems [39].

The potential of $A$. muricata leaves extracts to reduce ferric III iron was observed by FRAP method. The reducing properties of plant extracts, via hydrogen 
atom donation, are generally attributed to the presence of reductones, which exert an antioxidant action by breaking the free radical chains [40]. Comparative to the DPPH method, the inhibition percentage of ferric III iron was lowest $(55.03 \% \pm 0.04 \%)$ than $80.59 \% \pm 0.58 \%$ obtained with the DPPH method. The same observation were made by others authors [41] [42] who show that the inhibition percentage and $\mathrm{IC}_{50}$ values varies according to DPPH, FRAP, Nitric Oxide, Hydroxyl radical, Superoxyde radical, Lipid peroxidation methods. According to DPPH and FRAP methods used in this study $A$. muricata extracts have antioxidant activity. Ngueguim et al. [43] show also antioxidant capacity of A. muricata leaves extracts with different methods. The antioxidant activity of $A$. muricata leaves extracts observed in the present study would be link to their chemical composition. Indeed, HPLC analysis performed with the extract revealed the presence of various ployphenolic compounds such as gallic acid, chlorogenic acid, cafeic acid, tannic acid, ferrulic acid, Rutin, Ellargic acid. Tannic acid was the major identified components, this phenolic acid was known to promote antioxydant activity [44] [45]. Others compounds identified by HPLC are reported to have antioxidant activity. It is the case of gallic acid [46] [47], caffeic acid, chlorogenic acid [48], Rutin [49], Ellagic acid [50] ferrulic acid [48] [51].

The efficacies of herbal medicines about chronic inflammatory activity have been studied in many previous cases. In the present study the protein denaturation bioassay was selected for in vitro assessment of anti-inflammatory activity of $A$. muricata leaves extracts. Denaturation of tissue proteins is one of the well-documented causes of inflammatory and arthritic diseases. Production of auto antigens in certain inflammatory diseases may be due to in vivo denaturation of proteins. Agents that can prevent protein denaturation therefore, would be worthwhile for anti-inflammatory drug development. In the present study, compared to diclofenac used as reference molecule, the experimental results show that the ethanolic and hemi-ethanolic extracts of $A$. muricata display the good anti-inflammatory activity with significant difference $(p<0.0001)$ between inhibition percentage of protein (egg albumin) denaturation. The presence of flavonoids in the both extracts could be the basis of the better activity showed by these extracts. Flavonoids have been considered to possess significant anti-inflammatory properties, both in vitro and in vivo [52] [53].

Referring to the toxicity scale established by Moshi et al. [17], the ethanolic and hemi-ethanolic extracts $\mathrm{LD}_{50}$ is greater than $0.1 \mathrm{mg} / \mathrm{ml}$, value above which the extract is considered exhibiting no toxicity. Indeed, A. muricata tested extracts are not toxic at the tested doses. However, the brine shrimp ( $A$. salina) mortality increased with the increasing of $A$. muricata extracts concentration.

\section{Conclusion}

Through the obtained results, we can conclude that $A$. muricata contains many secondary metabolites dominated by polyphenolic compounds. HPLC analysis 
performed with the extract revealed the presence of various ployphenolic compounds such as gallic acid, chlorogenic acid, cafeic acid, tannic acid, ferrulic acid, Rutin. The presence of these compounds confers to $A$. muricata leaves, through the ethanolic and the hemi-ethanolic extracts, the antioxidant and anti-inflammatory activities.

\section{Conflicts of Interest}

The authors declare no conflicts of interest regarding the publication of this paper.

\section{References}

[1] Jamil, M.M.A., Ganeson, S., Mammam, H.B. and Wahab, R.A. (2018) Artocarpus altilis Extract Effect on Cervical Cancer Cells. Materials Today: Proceedings, 5, 15559-15566. https://doi.org/10.1016/j.matpr.2018.04.163

[2] Krishnan, G.S., Sebastian, D., Savarimuthu, I., Poovathumkal, J.A. and Fleming, A.T. (2017) In Vitro and in Silico Anticancer Effect of Combined Crude Acetone Extracts of Plumbago zeylanica L., Limonia acidissima L. and Artocarpus heterophyllus Lam. Synergy, 5, 15-23. https://doi.org/10.1016/j.synres.2017.11.003

[3] Ashraf, A., Sarfraz, R.A., Mahmood, A. and Ud Din, M. (2015) Chemical Composition and in Vitro Antioxidant and Antitumor Activities of Eucalyptus camaldulensis Dehn. Leaves. Industrial Crops and Products, 74, 241-248.

https://doi.org/10.1016/j.indcrop.2015.04.059

[4] Dasgupta, P. (2007) Nature and the Economy. Journal of Applied Ecology, 44, 475-487. https://doi.org/10.1111/j.1365-2664.2007.01316.x

[5] Terrill, J.R., Radley-Crabb, H.G., Iwasaki, T., Lemckert, F.A., Arthur, P.G. and Grounds, M.D. (2013) Oxidative Stress and Pathology in Muscular Dystrophies: Focus on Protein Thiol Oxidation and Dysferlinopathies. FEBS Journal, 280, 4149-4164. https://doi.org/10.1111/febs.12142

[6] Halliwell, B. and Gutteridge, J.M. (2007) Free Radicals in Biology and Medicine, Vol. 4. Oxford University Press, New York.

[7] Russo, G.L., Tedesco, I., Spagnuolo, C. and Russo, M. (2017) Antioxidant Polyphenols in Cancer Treatment: Friend, Foe or Foil? Seminars in Cancer Biology, 46, 1-13. https://doi.org/10.1016/j.semcancer.2017.05.005

[8] Kim, M.S., Nama, M. and Hwanga, G.S. (2018) Metabolic Alterations in Two Cirsium Species Identified at Distinct Phenological Stages Using UPLC-QTOF/MS. Phytochemical Analysis, 29, 77-86. https://doi.org/10.1002/pca.2716

[9] Alam, M.A., Subhan, N., Rahman, M.M., Uddin, S.J., Reza, H.M. and Sarker, S.D. (2014) Effect of Citrus Flavonoids, Naringin and Naringenin, on Metabolic Syndrome and Their Mechanisms of Action. Advances in Nutrition, 5, 404-417. https://doi.org/10.3945/an.113.005603

[10] Mittal, M., Siddiqui, M.R., Tran, K., Reddy, S.P. and Malik, A.B. (2014) Reactive Oxygen Species in Inflammation and Tissue Injury. Antioxydant \& Redox Signaling, 20, 1126-1167. https://doi.org/10.1089/ars.2012.5149

[11] Aitken, S.L., Karcher, E.L. and Rezamand, P. (2009) Evaluation of Antioxidant and Proinflammatory Gene Expression in Bovine Mammary Tissue during the Periparturient Period. Journal of Dairy Science, 92, 589-598.

https://doi.org/10.3168/jds.2008-1551 
[12] Wallace, J.L. and Ferraz, J.G. (2010) New Pharmacologic Therapies in Gastrointestinal Disease. Gastroenterology Clinics of North America, 39, 709-720. https://doi.org/10.1016/j.gtc.2010.08.020

[13] Vonkeman, H.E. and van de Laar, M.A. (2010) Nonsteroidal Anti-Inflammatory Drugs: Adverse Effects and Their Prevention. Seminars in Arthritis Rheumatisms, 39, 294-312. https://doi.org/10.1016/j.semarthrit.2008.08.001

[14] Kumarasamy, Y., Byres, M., Cox, P.J., Jaspars, M., Nahar, L. and Sarker, S.D. (2007) Screening Seeds of Some Scottish Plants for Free Radical Scavenging Activity. Phytotherapy Research, 21, 615-621. https://doi.org/10.1002/ptr.2129

[15] Costa, J.P., Pinheiro, M.J.F., Sousa, S.A., Botelho do Rego, A.M., Marques, F., Oliveira, M.C., Leitão, J.H., Mira, P., Carvalho, N. and Fernanda, M. (2019) Antimicrobial Activity of Silver Camphorimine Complexes against Candida Strains. Antibiotics (Basel, Switzerland), 8, pii E144. https://doi.org/10.3390/antibiotics8030144

[16] Ibrahim, N.S. and Abdullahi, M. (2015) Cytotoxicity, Total Phenolic Contents and Antioxidant Activity of the Leaves Extract of Annona Muricata. ChemSearch Journal, 6, 46-51. https://www.ajol.info/index.php/csj/article/view/119475

[17] Moshi, M.J., Cosam, J.C., Mbwambo, Z.H., Kapingu, M. and Nkunya, M.H.H. (2004) Testing beyond Ethnomedical Claims: Brine Shrimp Lethality of Some Tanzanian Plants. Pharmaceutical Biology, 42, 547-551. https://doi.org/10.3109/13880200490897920

[18] Elizângela, B.B., Edinardo, F.F.M., Francisco, E.B.J., Dayanne, R.O., Henrique, D.M.C., Jose, G.M.C., Marta, R.K. and Irwin, R.A.M. (2013) Association between Food and Drugs: Antimicrobial and Synergistic Activity of Annona muricata L. International Journal of Food Properties, 16, 738-744. https://doi.org/101080/109429122011565905

[19] Luna Jde, S., De Carvalho, J.M., De Lima, M.R., Bieber, L.W., Bento Ede, S., Franck, X. and Sant'ana, A.E. (2006) Acetegenins in Annona muricata L. (Annonaceae) Leaves Are Potent Molluscicides. Natural Products Research, 20, 253-257. https://doi.org/10.1080/14786410500161445

[20] Roslida, A.H., Tay, C.E., Zuraini, A. and Chan, P.F. (2010) Anti-Inflammatory and Antinociceptive Activities of the Ethanolic Extract of Annona muricata Leaf. Journal of Natural Remedies, 10, 97-104.

[21] Leboeuf, M., Cave, A., Bhaumik, P.K., Mukherjee, B. and Mukherjee, R. (1980) The Phytochemistry of the Annonaceae. Phytochemistry, 21, 2783-2813.

https://doi.org/10.1016/0031-9422(80)85046-1

[22] Kossouoh, C., Moudachirou, M. and Adjakidje, V. (2007) Essential Oil Chemical Composition of Annona muricata L. Leaves from Benin. Journal of Essential Oil Research, 19, 307-309. https://doi.org/10.1080/10412905.2007.9699288

[23] Chang, F.R., Liaw, C.C. and Lin, C.Y. (2003) New Adjacent Bistetrahydrofuran Annonaceous Acetogenins from Annona muricata. Planta Medica, 69, 241-246. https://doi.org/10.1055/s-2003-38485

[24] Dah-Nouvlessounon, D., Adoukonou-Sagbadja, H., Diarrassouba, N., Sina, H., Noumavo, P.A., Baba-Moussa, F., Adjanohoun, A., Gbenou, J.D. and Baba-Moussa, L. (2015) Antimicrobial, Antioxidant, Cytotoxic Activities and Phytochemical Assessment of Cola acuminata Used in Benin. International Journal of Pharmacy and Pharmaceutical Sciences, 7, 102-109.

https://innovareacademics.in/journals/index.php/ijpps/article/view/5654

[25] Houghton, D.J.P. and Raman, A. (1998) Laboratory Handbook for the Fractionation of Natural Extracts. Chapman and Hall, London, 199 p. 
https://doi.org/10.1007/978-1-4615-5809-5

[26] Scherer, R. and Godoy, H.T. (2009) Antioxidant Activity Index (IAA) by the 2,2-diphenyl-1-picrylhydrazyl Method. Food Chemistry, 112, 654-658.

https://doi.org/10.1016/j.foodchem.2008.06.026

[27] Schmeda-Hirschmann, G., Rodriguez, J.A., Theoduloz, C., Astudillo, L., Feresin, G.E. and Tapia, A. (2003) Free Radical Scavengers and Antioxidants from Peumusboldus Mol. ("Boldo"). Free Radical Research, 37, 447-452. https://doi.org/10.1080/1071576031000090000

[28] Dieng, S.I.M., Fall, A.D., Diatta-Badji, K., Sarr, A., Sene, M., Sene, M., Mbaye, A., Diatta, W. and Bassene, E. (2017) Evaluation de l'activité antioxydante des extraits hydro-ethanoliques des feuilles et écorces de Piliostigma thonningii Schumach. International Journal of Biological and Chemical Science, 11, 768-776. https://doi.org/10.4314/ijbcs.v11i2.19

[29] Suchita, V.G., Mrunal, G.S., Varsha, M.J., Vilasrao, J.K., Nilam, S. and Mira, R. (2017) Assessment of In-Vitro Anti-Inflammatory Activity of Cynodon dactylon and Acyclovir Showing Synergistic Effect by Albumin Denaturation and Membrane Stabilization Assay. Modern Approaches in Drug Designing, 1, 1-5.

https://doi.org/10.31031/MADD.2017.01.000506

[30] Kawsar, S.M.A., Huq, E. and Nahar, N. (2008) Cytotoxicity Assessment of the Aerial Part of Macrotyloma uniflorum Lim. International Journal of Pharmacy, 4, 297-300. https://doi.org/10.3923/ijp.2008.297.300

[31] Pereira, J.A., Oliveira, I., Sousa, A., Valentao, P., Andrade, B.P. and Ferreira, C.F.R.I. (2007) Walnut (Juglans regia L.) Leaves: Phenolic Compounds, Antibacterial Activity and Antioxidant Potential of Different Cultivars. Food and Chemical Toxicology, 45, 2287-2295. https://doi.org/10.1016/j.fct.2007.06.004

[32] Katalinic, V., Milos, M., Modun, D., Music, I. and Boban, M. (2004) Antioxidant Effectiveness of Selected Wines in Comparison with (+)-catechin. Food Chemistry, 86, 93-600. https://doi.org/10.1016/j.foodchem.2003.10.007

[33] Ortuno, A., Baidez, A., Gomez, P., Arcas, M.C., Porras, I., Gracia-Lidon, A. and De Rio, J.A. (2006) Citrus Paradisi and Citrus sinensis Flavonoids: Their Influence in the Defence Mechanism against Penicillium digitatum. Food Chemistry 98, 351-358. https://doi.org/10.1016/j.foodchem.2005.06.017

[34] Serafini, M., Peluso, I. and Ragguzzini, A. (2010) Flavonoids as Antiinflammatory Agents. Proceedings of the Nutrition Society, 69, 273-278. https://doi.org/10.1017/S002966511000162X

[35] Jiang, H., Zhan, W.Q., Liu, X. and Jiang, S.X. (2008) Antioxidant Activities of Extracts and Flavonoid Compounds from Oxytropis Falcate Bunge. Natural Products Research, 22, 1650-1656. https://doi.org/10.1080/14786410701875686

[36] Fernández-Pachón, M.S., Villaño, D., Troncoso, A.M. and García-Parrilla, M.C. (2006) Determination of the Phenolic Composition of Sherry and Table White Wines by Liquid Chromatography and Their Relation with Antioxidant Activity. Analytica Chimica Acta, 563, 101-108. https://doi.org/10.1016/j.aca.2005.09.057

[37] Baskar, R., Rajeswari, V. and Sathish Kumar, T. (2007) In Vitro Antioxidant Studies in Leaves of Annona Species. Indian Journal of Experiemental Biology, 45, 480-485. https://www.ncbi.nlm.nih.gov/pubmed/17569293

[38] George, V.C., Naveen Kumar, D.R., Suresh, P.K. and Ashok Kumar, R. (2015) Antioxidant, DNA Protective Efficacy and HPLC Analysis of Annona muricata (Soursop) Extracts. Journal of Food Science and Technology, 52, 2328-2335. https://doi.org/10.1007/s13197-014-1289-7 
[39] Halliwell, B., Aeschbach, R., Loliger, J. and Aruoma, O.I. (1995) The Characterization of Antioxidants. Food Chemical Toxicology, 33, 601-617. https://doi.org/10.1016/0278-6915(95)00024-V

[40] Duh, P.D., Du, P.C. and Yen, G.C. (1999) Action of Methanolic Extract of Mung Hulls as Inhibitors of Lipid Peroxidation and Non-Lipid Oxidative Damage. Food and Chemical Toxicology, 37, 1055-1061. https://doi.org/10.1016/S0278-6915(99)00096-4

[41] Rezaeizadeh, A., Zuki, A.B.Z., Abdollahi, M., Goh, Y.M., Noordin, M.M., Hamid, M. and Azmi, T.I. (2011) Determination of Antioxidant Activity in Methanolic and Chloroformic Extracts of Momordica charantia. African Journal of Biotechnology, 10, 4932-4940. https://www.ajol.info/index.php/ajb/article/view/94172

[42] Cudalbeanu, M., Furdui, B., Cârâc, G., Barbu, V., Iancu, A.V., Marques, F., Leitão, J.H., Sousa, S.A. and Dinica, R.M. (2019) Antifungal, Antitumoral and Antioxidant Potential of the Danube Delta Nymphaea alba Extracts. Antibiotics, 9, 1-25. https://doi.org/10.3390/antibiotics9010007

[43] Ngueguim, T.F., Massa, Z.B., Kouamouo, J., Tchuidjang, A., Dzeufiet, D.P.D., Kamtchouing, P. and Dimo, T. (2014) Antidiabetic and Antioxidant Effects of $A n-$ nona muricata (Annonaceae), Aqueous Extract on Streptozotocin-Induced Diabetic Rats. Journal of Ethnopharmacology, 151, 784-790. https://doi.org/10.1016/j.jep.2013.09.021

[44] Lou, W., Chen, Y., Ma, H., Liang, G. and Liu, B. (2018) Antioxidant and a-Amylase Inhibitory Activities of Tannic Acid. Journal of Food Sciences and Technology, 55, 3640-3646. https://doi.org/10.1007/s13197-018-3292-x

[45] Gupta, A., Singh, A.K., Kumar, R., Gangul, R., Rana, H.K., Pandey, K.P., Sethi, G., Bishayee, A. and Pandey, A.K. (2019) Corilagin in Cancer: A Critical Evaluation of Anticancer Activities and Molecular Mechanisms. Molecules, 24, 33-99. https://doi.org/10.3390/molecules24183399

[46] Li, S., Ye, T., Liang, L., Liang, W., Jian, P., Zhou, K. and Zhang, L. (2018) Anti-Cancer Activity of an Ethyl-Acetate Extract of the Fruits of Terminalia bellerica (Gaertn.) Roxb. through an Apoptotic Signaling Pathway in Vitro. Journal of Traditional Chinese Medical Sciences, 5, 370-379. https://doi.org/10.1016/j.jtcms.2018.11.006

[47] Rafiee, S.A., Farhoosh, R. and Sharif, A. (2018) Antioxidant Activity of Gallic Acid as Affected by an Extra Carboxyl Group than Pyrogallol in Various Oxidative Environments. European Journal of Lipid Science and Technology, 120, 18-39.

[48] Gil, M. and Wianowska, D. (2017) Chlorogenic Acids: Their Properties, Occurrence and Analysis. Annales Universitatis Mariae Curie Skłodowska Sectio AA Chemistry, 72, 61-72. https://doi.org/10.17951/aa.2017.72.1.61

[49] Iqbala, J., Abbasi, B.A., Batool, R., Mahmood, T., Ali, B., Khalil, A.T., Kanwal, S., Shah, S.A. and Ahmad, R. (2018) Potential Phytocompounds for Developing Breast Cancer Therapeutics: Nature's Healing Touch. European Journal of Pharmacology, 827, 125-148. https://doi.org/10.1016/j.ejphar.2018.03.007

[50] Abid, M., Yaich, H., Cheikhrouhou, S., Khemakhem, I., Bouaziz, M., Attia, H. and Ayadi, M.A. (2017) Antioxidant Properties and Phenolic Profile Characterization by LC-MS/MS of Selected Tunisian Pomegranate Peels. Journal of Food Science and Technology, 54, 2890-2901. https://doi.org/10.1007/s13197-017-2727-0

[51] Kim, K.J. and Park, S.U. (2019) A Recent Overview on the Biological and Pharmacological Activities of Ferulic Acid. EXCLI Journal, 18, 132-138.

[52] Vasudevan, M., Gunman, K.K. and Parle, M. (2007) Antinociceptive and An- 
ti-Inflammatory Effects of Thespesia populnea Bark Extract. Journal of Ethnopharmacology, 109, 264-270. https://doi.org/10.1016/j.jep.2006.07.025

[53] Raja, C., Biplab, D., Nayakanti, D. and Saikat, S. (2012) Anti-Inflammatory, Antinociceptive and Antioxidant Activities of Phyllanthus acidus L. Extracts. Asian Pacific Journal of Tropical Biomedicine, 2, 953-961.

https://doi.org/10.1016/S2221-1691(12)60343-8 